\title{
Regional differences in the life cycle of Calanoides acutus (Copepoda: Calanoida) within the Atlantic sector of the Southern Ocean
}

\author{
A. Atkinson ${ }^{1, *}$, S. B. Schnack-Schiel ${ }^{2}$, P. Ward ${ }^{1}$, V. Marin ${ }^{3}$ \\ 'British Antarctic Survey, Natural Environment Research Council, High Cross, Madingley Road, Cambridge CB3 0ET, \\ United Kingdom \\ ${ }^{2}$ Alfred-Wegener-Institut für Polar- und Meeresforschung, Columbusstrasse, D-27568 Bremerhaven, Germany \\ ${ }^{3}$ Universidad de Chile, Fac. Ciencias, Depto. Cs Ecologicas, Casilla 653, Santiago, Chile
}

\begin{abstract}
All suitable data from the Atlantic sector of the Southern Ocean were compiled to elucidate regional differences in the abundance and life cycle of Calanoides acutus. Data from 205 stations (1928 to 1992) were pooled into 3 regions, namely the Scotia Sea (SS), the Weddell-Scotia Confluence/ northern Weddell Sea area (WSC) and the Eastern Weddell Sea (EWS). The regions contrast sharply: the ice-free SS has summer mixed layer temperatures $\sim 3$ to $4^{\circ} \mathrm{C}$ higher but summer chlorophyll a concentrations generally lower than the EWS, which is ice-covered for three-quarters of the year $C$. acutus was rarer in the vicinity of the WSC than in the southern part of the SS or in the EWS. In all 3 regions seasonal vertical migration characterised the populations, but thelr appearance in the surface waters of the SS was 1 to 2 mo earlier than in the EWS, and was of longer duration. Because C. acutus is herbivorous, this is presumably a response to the timing of summer primary production. Despite the contrasting environments, spring/summer development rates were similar in all 3 regions, with moulting from copepodid CI to CIV taking approx $1.5 \mathrm{mo}$. Population mortality in autumn/winter was $0.0070 \mathrm{~d}^{-1}$ in the SS and $0.0059 \mathrm{~d}^{-1}$ in the EWS; highly variable abundance in the WSC area precluded mortality estimation. Based on summer moulting rates, winter stage structure and mortality rates, the life cycle appears to be completed normally within 1 yr in all 3 regions, but it is suggested that the shorter summer growth season in the EWS results in a small proportion of the population taking 2 yr to reach adulthood.
\end{abstract}

KEY WORDS: Southern Ocean Copepod Calanoides acutus Life cycle Generation time - Mortality

\section{INTRODUCTION}

Calanoides acutus is a major contributor to zooplankton biomass in the Southern Ocean (Hopkins 1971, Voronina 1978) with a circumpolar distribution (Baker 1954) and high abundance within both the Antarctic Circumpolar Current and the East Wind Drift. Numerous studies address its distribution and life cycle, dating from Ottestad (1932). The main events in its life cycle were documented by Vervoort (1965) and Andrews (1966), with the latter author drawing on a large number of samples from the Discovery expeditions to describe the seasonal vertical

•E-mail:aat@pcmail.nerc-bas.ac.uk migration and monthly changes in age structure and gonad maturity. Voronina (1970) and Marin (1988) supplied further details, describing respectively latitudinal differences in timing of the life cycle and the mating period, which is concurrent with the appearance of adult males at depth in winter.

In the last decade, studies have expanded rapidly in scope, supplying information on development rates (e.g. Atkinson 1991, Huntley \& Escritor 1991, Lopez et al. 1993), diet and feeding (e.g. Schnack-Schiel et al. 1991, Atkinson et al. 1992، Hopkins et al. 1993, Pasternak et al. 1994), abundance and vertical distribution (e.g. Marin 1987, Bathmann et al. 1993, Schnack-Schiel \& Hagen 1995) and lipid storage (e.g. Graeve et al. 1994, Kattner et al. 1994, Pasternak et al. 1994, Hagen \& Schnack- 
Schiel 1996). Unlike the other large Antarctic copepods Calanus propinquus and Rhincalanus gigas, for which the findings are sometimes contradictory, these studies have reached a consensus on some aspects of the life cycle of $C$. acutus. It is known that mating occurs at depth during winter, that fertilized females ascend to the surface layers for the egg laying period in spring/summer and that feeding is mainly on phytoplankton near the surface in summer. This gives rise to an extensive store of long chain wax esters in CIV and CV, a cessation of feeding and an autumnal descent to mainly between 500 and $1500 \mathrm{~m}$, for overwintering in diapause. However, some major uncertainties remain, namely the rate of moulting in summer (Andrews 1966. Atkinson 1991, cf. Huntley \& Escritor 1991) and the overall duration of the life cycle. Until recently it had been accepted that the life span was 1 yr, but Pasternak et al. (1994) and Drits et al. (1994) have suggested that it takes 2 yr to develop from egg to mature female. Recent lipid data have led Hagen \& Schnack-Schiel (1996) to suggest that some females may survive a further year after spawning.

A major cause of these uncertainties is the logistical difficulty of obtaining seasonal coverage from a vast and remote ocean. The dynamic circulation in the Southern Ocean (Gordon 1988, Huntley \& Niiler 1995) and the fact that it comprises distinct sub-systems (Tréguer \& Jacques 1992) also conspire to alias regional and seasonal differences (Ommanney 1936 , Voronina 1978). In this study we have attempted to counter these problems by compiling all suitable published data on the age structure of Calanoides acutus in the Atlantic sector. Numerous data from different

Table 1. Scotia Sea stations selected for analysis. Falks: Falkland Islands; SS: Scotia Sea; AKN: RV 'Akademik Knipovich'; JB: RV 'John Biscoe'; WS: RV 'William Scoresby'; E: RV 'Eltanin'; D: RV 'Discovery Il'; P: RV 'Polarstern'; AKU: RV 'Akademik Kurchatov' Stations sampled at similar times of year have been grouped, to enable summary plotting of data (see Figs. 3-5). Unpubjished data from RV 'Polarstern' is held by S. B. Schnack-Schiel

\begin{tabular}{|c|c|c|c|c|c|c|}
\hline Date & $\begin{array}{l}\text { Position of } \\
\text { stations }\end{array}$ & Shıp & Stations & $\begin{array}{l}\text { Net depth, }(\mathrm{m}) \\
\text { (no, of strata) }\end{array}$ & Source & Notes \\
\hline 5-7 Aug 1971 & Falks to S. Georgia & $\mathrm{AKN}$ & $34,35,36,37,38,39$ & $1000(5)$ & Voronina et al. (1978) & $\%$ oniy \\
\hline 27 Jul-20 Aug 1983 & Near S. Georgia & $J \mathrm{~B}$ & (12 unnamed stations) & $1000(3)$ & Atkinson $(1989)$ & RMT1 \\
\hline 20-24 Aug 1928 & Falks to S. Georgia & WS & $252,253,254,255,256$ & $1000(6)$ & Atkinson (1991) & \\
\hline 1 Sept 1963 & South of S. Georgia & E & 180 & $2000(3)$ & Marin (1988) & \\
\hline Sept 1971 & Southern SS & AKN & 114 & $1000(6)$ & Vladimirskaya (1978) & \\
\hline 26 Sept 1971 & Eastern SS & AKN & 111 & $1000(5)$ & Voronina et al. (1978) & $\%$ only \\
\hline 8 Oct 1971 & Central SS & AKN & 142 & $1000(5)$ & Voroninat et al. (1978) & $\%$ only \\
\hline $26-28$ Oct 1932 & Along $80^{\circ} \mathrm{W}$ & $\mathrm{D}$ & $987,989,991,993$ & $1000(6)$ & Atkinson (1991) & \\
\hline $\begin{array}{l}13 \text { Nov } 1988 \\
9-13 \text { Nov } 1929\end{array}$ & $\begin{array}{l}\text { Southern SS } \\
\text { Across SS }\end{array}$ & $\stackrel{p}{\text { WS }}$ & $\begin{array}{l}139 \\
468,469,470,471,473\end{array}$ & $\begin{array}{l}1000(5) \\
1000(6)\end{array}$ & $\begin{array}{l}\text { Unpubl data } \\
\text { Atkinson (1991) }\end{array}$ & \\
\hline $\begin{array}{l}26 \text { Nov } 1988 \\
18-20 \text { Nov } 1932\end{array}$ & $\begin{array}{l}\text { Southern SS } \\
\text { East SS }\end{array}$ & $\begin{array}{l}\mathrm{P} \\
\mathrm{D}\end{array}$ & $\begin{array}{l}143 \\
1028,1030\end{array}$ & $\begin{array}{l}1000(5) \\
1000(6)\end{array}$ & $\begin{array}{l}\text { Unpubl, data } \\
\text { Atkinson (1991) }\end{array}$ & \\
\hline 2-5 Dec 1928 & S. Georgia to Falks & ws & $315,316,317,318$ & $1000(6)$ & Atkinson (1991) & \\
\hline 11-13 Dec 1988 & Southern SS & $\mathrm{P}$ & $159 b, 160,162$ & $1000(5)$ & Unpubl. data & \\
\hline 13-14 Dec 1971 & Central SS & $\mathrm{AKU}$ & 912,915 & $1000(5)$ & Voronina et al. (1978) & $\%$ only \\
\hline $\begin{array}{l}\text { 27-28 Dec } 1988 \\
28 \text { Dec-1 Jan } 1934\end{array}$ & $\begin{array}{l}\text { Southern SS } \\
\text { Drake: Passage }\end{array}$ & $\begin{array}{l}\mathrm{P} \\
\mathrm{D}\end{array}$ & $\begin{array}{l}182,186 \\
1233,1234,1235,1236,1237\end{array}$ & $\begin{array}{l}1000(5) \\
1000(5-6)\end{array}$ & $\begin{array}{l}\text { Unpubl. data } \\
\text { Atkinson (1991) }\end{array}$ & \\
\hline $\begin{array}{l}\text { 18-21 Jan } 1990 \\
17 \text { Jan } 1989\end{array}$ & $\begin{array}{l}\text { Near S. Georgia } \\
\text { Southern SS }\end{array}$ & $\begin{array}{l}J B \\
P\end{array}$ & $\begin{array}{l}\text { Unnamed station } \\
213\end{array}$ & $\begin{array}{l}800(-21) \\
1000(5)\end{array}$ & $\begin{array}{l}\text { Ward et al. (1995) } \\
\text { Unpubl. data }\end{array}$ & \\
\hline $24-25$ Jan 1935 & Central SS & D & $1493,1494,1495$ & $1000(6)$ & Atkinson (1991) & \\
\hline Jan/Feb 1966 & Central/northern SS & $E$ & $515,521,522$ & $1000(5)$ & Marin (1986) & \\
\hline 27 Jan-5 Feb 1985 & S. Shetlands area & JB & $34,35,42,44,49,50,51$ & $500(2)$ & Unpubl. SIBEX data & RMT1 \\
\hline $\begin{array}{l}9-15 \text { Feb } 1928 \\
22-24 \text { Feb } 1929\end{array}$ & $\begin{array}{l}\text { Falks to S. Georgia } \\
\text { Drake Passage }\end{array}$ & $\begin{array}{l}\text { WS } \\
\text { WS }\end{array}$ & $\begin{array}{l}138,139,140,141,143 \\
402,403,404,405\end{array}$ & $\begin{array}{l}1000(5-6) \\
1000(6)\end{array}$ & $\begin{array}{l}\text { Atkinson (1991) } \\
\text { Atkinson (1991) }\end{array}$ & \\
\hline 27 Feb-3 Mar 1930 & Falks to S. Georgia & WS & $520,521,522,523,524,526$ & $1000(6)$ & Atkinson (1991) & \\
\hline $\begin{array}{l}\text { 4-7 Apr } 1930 \\
22-26 \text { Apr } 1928 \\
29 \text { Apr-1 May } 1929\end{array}$ & $\begin{array}{l}\text { Central SS } \\
\text { Central SS } \\
\text { S. Georgia to Falks }\end{array}$ & $\begin{array}{l}\text { D } \\
\text { WS } \\
\text { WS }\end{array}$ & $\begin{array}{l}1335,1337 \\
203,204,205 \\
428,429,430,431\end{array}$ & $\begin{array}{l}1000(6) \\
1000(6) \\
1000(6)\end{array}$ & $\begin{array}{l}\text { Atkinson (1991) } \\
\text { Atkinson (1991) } \\
\text { Atkinson (1991) }\end{array}$ & \\
\hline $\begin{array}{l}28-29 \text { May } 1936 \\
21-25 \text { June } 1951\end{array}$ & $\begin{array}{l}\text { Along } 0^{\circ} \text { meridian } \\
W \text { of Drake Passage }\end{array}$ & $\begin{array}{l}\mathrm{D} \\
\mathrm{D}\end{array}$ & $\begin{array}{l}1776,1777 \\
2842,2844\end{array}$ & $\begin{array}{l}1500(7) \\
1500(7)\end{array}$ & $\begin{array}{l}\text { Atkinson (1991) } \\
\text { Atkinson (1991) }\end{array}$ & \\
\hline 6-8 July 1951 & Central/eastern SS & $\mathrm{D}$ & $2849,2850,2851$ & $1500(7)$ & Atkinson (1991) & \\
\hline
\end{tabular}


years have therefore been condensed into a 'seasonal' composite, in order to elucidate regional differences in the life cycle. The Atlaritic sector was selected because its major sub-systems, the Scotia and Weddell Seas, are among the best studied parts of the Southern Ocean. We have focussed on aspects of distribution and life cycle which are still uncertain, namely on whether there are regional differences in abundance, moulting rates or timing of the life cycle, and whether the life cycle is 1 or $2 \mathrm{yr}$.

\section{METHODS}

Data set. We have used all available published and unpublished data sets on abundance and developmental stage structure in the sector from $0^{\circ}$ to $80^{\circ} \mathrm{W}$ (Tables 1 to 3, Fig. 1). Three selection criteria, however, excluded a large quantity of potentially confounding data. First, to exclude 'shelf effects' on the life cycle (Atkinson \& Peck 1990, Schnack-Schiel \& Hagen 1995) all hauls from water shallower than $1000 \mathrm{~m}$ were excluded. Second, oceanic stations were excluded if sampling was not to at least $1000 \mathrm{~m}$, in order to cover the bulk of the population of Calanoides acutus. Exceptions were a series of mid summer SIBEX (Second International Biological Experiment) stations, where sampling was to $500 \mathrm{~m}$ (Tables 1 \& 2). Third, the data set was restricted to samples collected with $200 \mu \mathrm{m}$ mesh nets or smaller, but again with the exception of the SIBEX stations and a mid winter survey around South Georgia, where $330 \mu \mathrm{m}$ mesh Rectangular Midwater Trawl (RMT1) nets were used (Table 1). Our justification for including the valuable South Georgia and SIBEX data was that the vertical distribution and age structures obtained in both surveys were such that the large majority of the population was sampled by the nets and retained in their meshes.

Most sampling was with opening/closing nets. N70V nets were used on the Discovery expeditions (Atkinson 1991) and Multinets were used for most of the sampling in the Weddell-Scotia Confluence area and the Eastern Weddell Sea (see Bathmann et al. 1993, Schnack-Schiel \& Hagen 1994). Volume of water filtered was calculated either from flowmeter data or from the product of net mouth area and vertical distance of tow. A different design of net was used on the post-war Discovery expeditions, so all post-war abun-

Table 2. Weddell-Scotia Confluence area. Stations selected for analysis. See Table 1 for abbreviations. Unpublished data from RV 'Polarstern' is held by S. B. Schnack-Schiel

\begin{tabular}{|c|c|c|c|c|c|c|}
\hline Date & $\begin{array}{l}\text { Position of } \\
\text { stations }\end{array}$ & Ship & Stations & $\begin{array}{l}\text { Vet depth, (m) } \\
\text { (no. of strata) }\end{array}$ & Source & Notes \\
\hline Aug-Sep 1963 & S. Orkneys area & E & $\begin{array}{l}178,179,181 / 183 \\
183 / 184,185\end{array}$ & $1000(?)$ & Marın (1986) & $\begin{array}{l}\% \text { only, net } \\
\text { to } 2000 \mathrm{~m} \text { at } \\
2 \text { stations }\end{array}$ \\
\hline 15 Sep 1988 & Western Weddell Sea & $\mathrm{P}$ & 154 & $1000(5)$ & Unpubl. data & \\
\hline Mid Sep 1971 & S. Orkneys area & AKN & $122,123,125$ & $1000(6)$ & Vladimirskaya (1978) & \\
\hline 14-21 Sep 1989 & S. Orkneys area & $\mathrm{P}$ & $151,154,156,158$ & $1000(5)$ & Bathmann et al. (1993) & $\begin{array}{l}\text { Net to } 2000 \mathrm{~m} \\
\text { at } 2 \text { stations }\end{array}$ \\
\hline 12 Nov 1988 & S. Orkneys area & $\mathrm{P}$ & $134,136,137$ & $1000(5)$ & Unpubl. data & \\
\hline $\begin{array}{l}21 \text { Nov } 1932 \\
27 \text { Nov }-5 \text { Dec } 1988\end{array}$ & $\begin{array}{l}\text { S. Orkneys area } \\
\text { S. Orkneys area }\end{array}$ & $\begin{array}{l}D \\
P\end{array}$ & $\begin{array}{l}1032 \\
145,14,7149,151,157 \mathrm{a}\end{array}$ & $\begin{array}{l}1000(6) \\
1000(5)\end{array}$ & $\begin{array}{l}\text { Atkinson (1991) } \\
\text { Unpubl. data }\end{array}$ & \\
\hline 28 Nov 1971 & West of S Georgia & $\mathrm{AKU}$ & 888 & $1000(5)$ & Voronina et al. (1978) & $\%$ only \\
\hline 14-16 Dec 1988 & S. Orkneys area & $P$ & $164,166,168$ & $1000(5)$ & Unpubl data & \\
\hline 29-31 Dec 1988 & S. Orkneys area & $\mathrm{P}$ & $188,190,192,194$ & $1000(5)$ & Unpubl. data & \\
\hline 8-11 Jan 1988 & Western Weddell Sea & $\mathrm{P}$ & $59,60,62,68$ & $1000[5]$ & Unpubl. data & \\
\hline 17-18 Jan 1989 & S. Orkneys area & $\mathrm{P}$ & $214,215,216,218$ & $1000(5)$ & Unpubl data & \\
\hline 23 Jan 1935 & S. Orkneys area & $\mathrm{D}$ & 1491,1492 & $1000(6)$ & Atkinson (1991) & \\
\hline 16 Jan-3 Feb 1985 & S. Shetlands area & $J B$ & $\begin{array}{l}2,3,8,11,16,19 \\
33,40,47\end{array}$ & $500(2)$ & Unpubl. SIBEX data & \\
\hline 21 Feb 1929 & S. Shetlands area & WS & 400 & $1000(6)$ & Atkinson (1991) & \\
\hline March-Apríl 1964 & $\begin{array}{l}\text { S. Shetlands to } \\
\text { S. Sandwich Islands }\end{array}$ & $E$ & $274,275,278,287$ & $1000(5)$ & Marin (1986) & \\
\hline $\begin{array}{l}\text { 4-5 April } 1934 \\
22 \text { April } 1928\end{array}$ & $\begin{array}{l}\text { N from S. Orkneys } \\
\text { S. Orkneys area }\end{array}$ & W & $\begin{array}{l}1331,1333 \\
201\end{array}$ & $\begin{array}{l}1000(6) \\
1000(6)\end{array}$ & $\begin{array}{l}\text { Atkinson (1991) } \\
\text { Atkinson (1991) }\end{array}$ & \\
\hline 1-2 June 1936 & Along $0^{\circ}$ meridian & $\mathrm{D}$ & 1779,1781 & $1000(6)$ & Atkınson (1991) & \\
\hline 9-10 July 1951 & South of S. Georgia & $\mathrm{D}$ & 2852,2853 & $1500(7)$ & Atkinson (1991) & \\
\hline
\end{tabular}




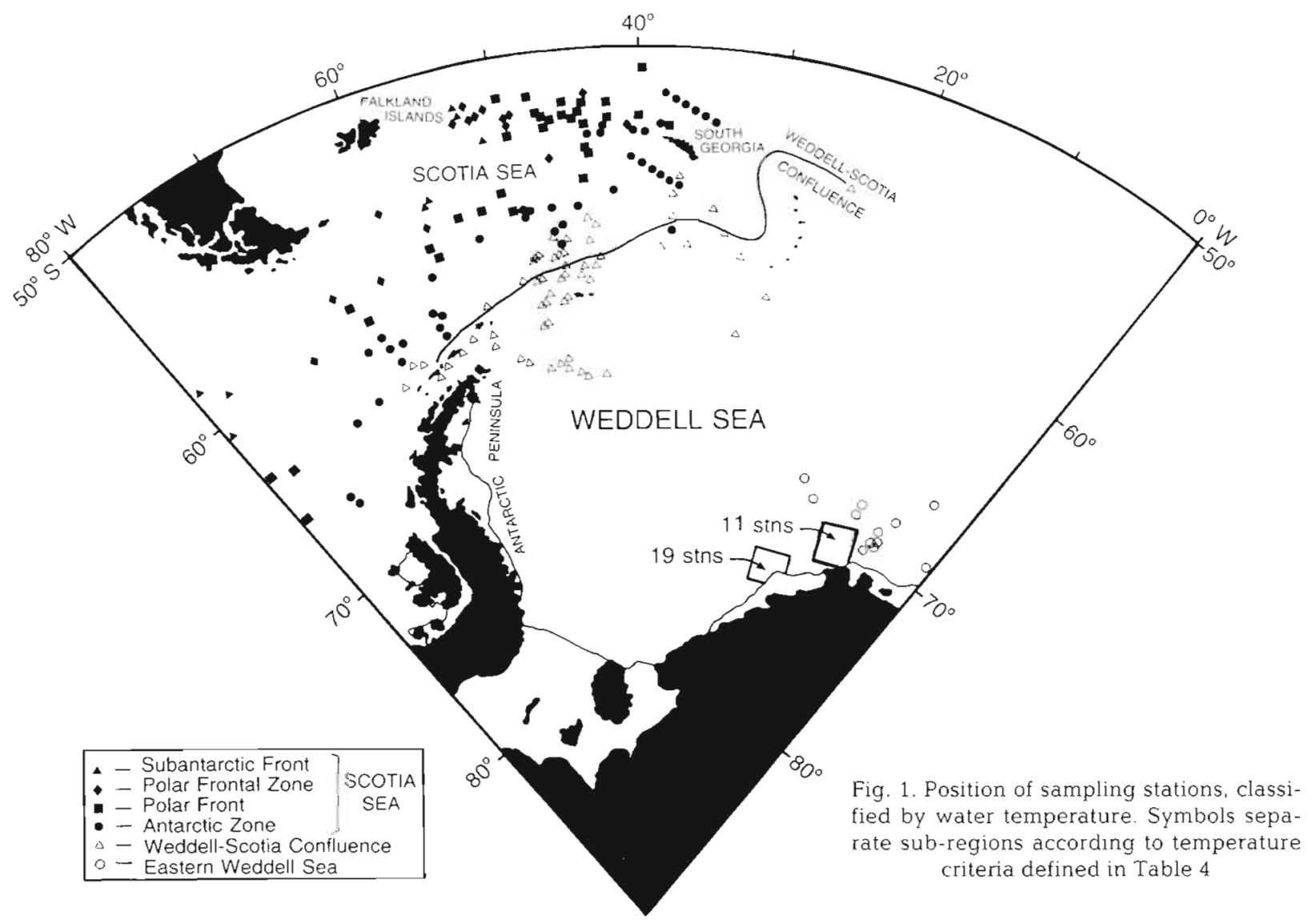

dance data have been multiplied by 1.5 following Foxton (1956).

Most of these data have been published previously, either as abundances of the individual copepodite stages in various depth horizons or in a few cases (see notes in Tables $1 \& 2$ ) as percentage stage frequencies within the top $1000 \mathrm{~m}$. The currently unpublished data were analysed using standard techniques isee Schnack-Schiel \& Hagen 1994), analysing aliquots of usually $1 / 2$ to $1 / 32$

Regional classification of stations. To investigate regional variability the study area was divided into 3

Table 3. Eastern Weddell Sea stations selected for analysis. All stations were worked by RV 'Polarstern'

\begin{tabular}{|c|c|c|c|c|}
\hline Date & Stations & $\begin{array}{l}\text { Net depth (m) } \\
\text { (no. of strata) }\end{array}$ & Source & Notes \\
\hline $\begin{array}{l}5-6 \text { Oct } 1988 \\
5-16 \text { Oct } 1989\end{array}$ & $\begin{array}{l}1 \text { unnamed station } \\
181,183,187,193,199,203\end{array}$ & $\begin{array}{l}1000(5) \\
2000(5)\end{array}$ & $\begin{array}{l}\text { Schnack-Schicl unpubl. data } \\
\text { Bathmann et al. (1993) }\end{array}$ & Net to $1.000 \mathrm{~m}$ at $\operatorname{Sin} 187$ \\
\hline $17-22$ Oct 1986 & $512,513,514,516,526$ & $1000(5)$ & Schnack-Schiel \& Hagen (1994) & \\
\hline 3-5 Nov 1986 & $562,565,570$ & $1000(5)$ & Schnack-Schiel \& Hagen (1994) & \\
\hline 17-24 Nov 1986 & $604,607,611,614,618,623$ & $1000(5)$ & Schnack-Schiel \& Hagen (1994) & \\
\hline 10-14 Dec 1990 & 94,108 & $1000(5)$ & Schnack-Schiel unpubl data & \\
\hline 14-22 Dec 1992 & $15,19,21,31$ & $1000(5)$ & Schnack-Schiel unpubl. data & \\
\hline 29 Jan 1985 & 278,279 & $1000(5)$ & Schnack-Schiel \& Hagen (1994) & \\
\hline 15 Feb 1985 & 332,333 & $1000(5)$ & Schnack-Schiel \& Hagen (1994) & \\
\hline 12-13 A.pr 1992 & $359,367,369,373$ & $1000(5)$ & Schnack-Schiel \& Hagen (1994) & \\
\hline $26 \mathrm{Apr}-2 \mathrm{Ma1} 1992$ & $452,455,461,467,472$ & $1000(5)$ & Schnack-Schiel \& Hagen (1994) & \\
\hline 17 Jun & 603 & $1000(5)$ & Schnack-Schiel unpubl. data & \\
\hline
\end{tabular}


regions, corresponding to different current systems and to distinct sub-systems (Tréguer \& Jacques 1992). These are the Scotia Sea (SS), the Eastern Weddell Sea (EWS) and the Weddell-Scotia Confluence/northern Weddell Sea (WSC). For stations in the transition between SS and WSC, classification is difficult (Marin 1987). A simple geographical grouping is inappropriate because of the dynamic nature of Southern Ocean fronts. Instead, following Atkinson (1991), classification was based on water temperature at depth. Water temperature is one of the few environmmental variables available in nearly all of the historical data and deep water temperatures were chosen to counteract the problem of variable seasonal warming in the upper mixed layer. The basis of this classification is shown in Table 4.

\section{RESULTS}

\section{Environment}

The SS and EWS are in separate current systems, the Antarctic Circumpolar Current and the East Wind Drift respectively. The concomitant differences in temperature, ice cover, length of growing season and chlorophyll a concentrations suggest quite different environments for Calanoides acutus between the warmest and coldest parts of its range (Table 5). The Antarctic Cir-

Table 4. Classification of stations according to their mean temperature at $400,600,800$ and $1000 \mathrm{~m}$ depth. Note that region headings are abbreviated titles; for instance the 'Weddell-Scotia Confluence' region encompasses stations in the northern Weddell Sea as well as in the Confluence itself

\begin{tabular}{|lll|}
\hline Region & Sub-region & $\begin{array}{l}\text { Temperature } \\
\text { range }\left({ }^{\circ} \mathrm{C}\right)\end{array}$ \\
\hline Scotia Sea & Subantarctic Front vicinity & $>2.68$ \\
& Polar Frontal Zone & $2.26-2.68$ \\
& Polar Front vicinity & $1.98-2.26$ \\
Antarctic Zone & $1.60-1.98$ \\
Weddell-Scotia & & $<1.6$ \\
Confluence & & $<0.8$ \\
lastern & & \\
Wrddell Sea & & \\
\hline
\end{tabular}

cumpolar Current flows mainly eastwards, unobstructed by major land masses and under the influence of a series of low pressure systems circulating at these latitudes (Nowlin \& Klinck 1986). The SS is part of the permanently open ocean zone, which is considered to be a high nutrient low chlorophyll (HNLC) zone (Jacques 1989). Compared to shelf-and ice-associated areas, chlorophyll a concentrations are generally low in this open ocean zone, although primary production can be elevated in the Polar Frontal Zone (Lutjeharms et al. 1985. Laubscher et al. 1993, Jochem et al. 1995).

The Weddell Sea, by contrast, is a large gyre in the slower moving East Wind Drift, under the influence of more stable high pressure systems associated with the Antarctic continent. The EWS region experiences about 3 ice-free months each year, from January to March (Gloersen et al. 1992). The WSC area is partly a transition zone between the above-mentioned current systems, and the environmental factors listed in Table 5 may reflect this. However, it has a complex frontal structure and the stations reflect varying influences of Scotia and Northern Weddell Water. Water from the northwest Weddell shelf can also be entrained into the WSC (Whitworth et al. 1994).

Chlorophyll a data are available for only a few of the stations, so regional differences in food availability had to be extracted from literature reviews (Table 5) Both the EWS and the WSC are reported to have higher mean summer chlorophyll a concentrations than the SS. Several factors may contribute to this. Firstly, stabilisation of the mixed layer due to melting sea ice can cause classical marginal ice zone blooms (Smith \& Nelson 1985, Sullivan et al. 1988). Secondly, the lower wind stress and sunnier summer weather nearer the Antarctic continent can mean better light regimes for growth (Lancelot et al. 1993). Thirdly, the proximity of the WSC and EWS to land masses upstream could lead to replenishment of trace nutrients including iron (Martin et al. 1990). Lastly, frontal dynamics (for the WSC) have been suggested to promote phytoplankton growth (Jacques \& Panouse 1991).

The above generalities, however, ignore the spatial and temporal heterogeneities within these subsystems. Authors are increasingly emphasising their variablity; for example, Jochem et al. (1995) found no

Table 5. Environmental differences between the 3 regions defined for the Atlantic sector. Chl a: chlorophyll a

\begin{tabular}{|llccl|}
\hline Environmental factor & Scotia Sea & Weddell-Scotla Confluence & Eastern Weddell Sea & Source \\
\hline Maximum water temperature & $9^{\circ} \mathrm{C}$ & $3^{\circ} \mathrm{C}$ & $1^{\circ} \mathrm{C}$ & Mackintosh (1946) \\
Duration of ice cover & Ice-free & $\sim 5 \mathrm{mo}$ & $\sim 9 \mathrm{mo}$ & Gloersen et al. (1992) \\
Mean chl a (October-March) & $1.1 \mathrm{mg} \mathrm{m}^{-3}$ & $2.1 \mathrm{mg} \mathrm{m}$ & $2.4 \mathrm{mg} \mathrm{m}^{-3}$ & Savidge et al. (1996) \\
Maximum chl a & $<2 \mathrm{mg} \mathrm{m}^{-3}$ & $<4 \mathrm{mg} \mathrm{m}^{-3}$ & $<4 \mathrm{mg} \mathrm{m}^{-3}$ ? & Tréguer \& Jacques (1992) \\
\hline
\end{tabular}




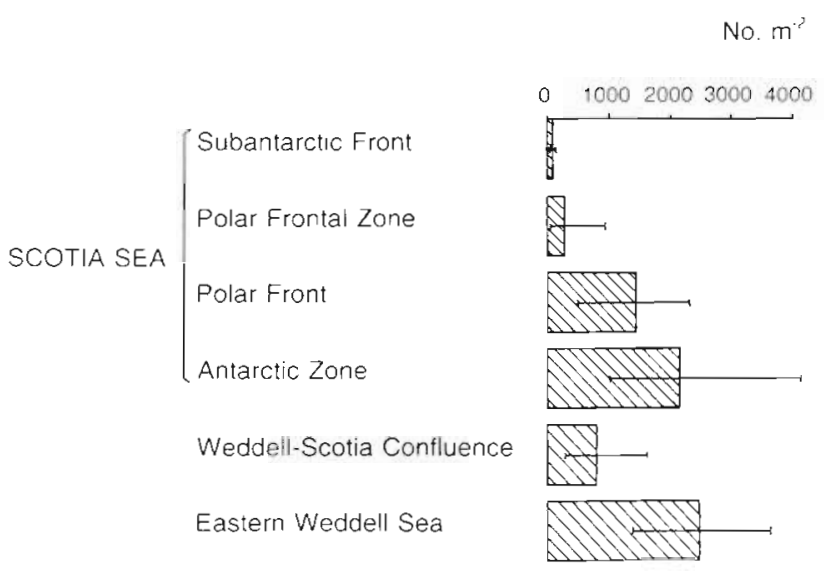

Fig. 2. Calanoides acutus. Median abundance in sub-regions of study area. Values are total copepodids under $1 \mathrm{~m}^{2}$ in the sampled water column. Bars represent interquartile ranges

springtime ice-edge bloom and Whitehouse et al (1996) noted a mid ocean bloom seemingly unconnected with any front or ice edge. Currently available data force us into simplified, basin-scale comparisons of both the oceanic environment and the life cycle of Calanoides acutus, which undoubtedly mask variability at other scales.

\section{Regional distribution}

Fig. 2 compares total copepodid abundance between the sub-regions defined in Table 4. The largest abundances are within the southern part of the SS and the EWS. Abundance declines sharply north of the Polar Front, and surprisingly, numbers are also low within the WSC area. A Mann-Whitney test showed a significantly $(p<0.01)$ lower abundance in the WSC compared to either the Antarctic Zone or the EWS stations. Because abundance of Calanoides acutus changes seasonally and coverage was on a 'seasonal' as well as regional basis, we checked whether the low abundance in the WSC was an artefact (e.g. a high proportion of WSC samples having been at times of year of expected low abundance) Therefore samples were first grouped into spring, summer, autumn and winter periods (see Atkinson 1991) and the averages of these were calculated. This seasonally weighted analysis substantiated the finding that $C$. acutus were rather scarce in the WSC area.

\section{Vertical distribution}

To show seasonal changes in vertical distribution of the population, stations sampled at similar times of year were pooled for the SS and the EWS (Tables $1 \& 3$ )

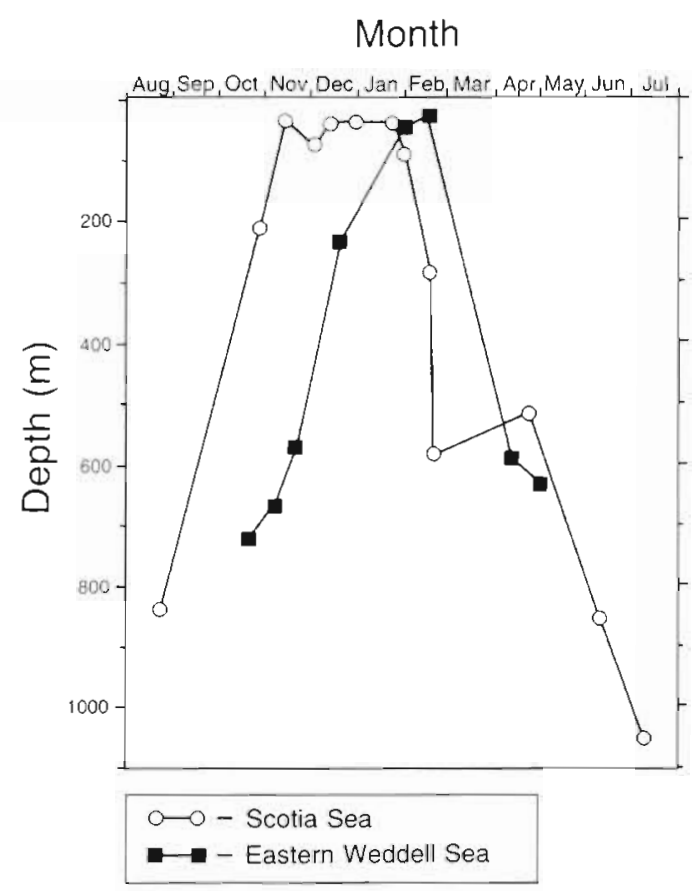

Fig. 3. Calanoides acutus. Median depth of the population Each point represents a group of stations in the Scotia Sea and Eastern Weddell Sea, as indicated in Tables 1 \& 3. Several groups could not be plotted because the depth strata sampled were not consistent within the group

and mean abundances within each depth stratum were calculated. Median population depths were then calculated for each station group (Fig. 3). The WSC is unlike the other 2 regions in that the vertical distribution of Calanoides acutus is highly variable, both among stations and throughout the summer The WSC region was omitted from Fig. 3 , and its variability is illustrated in Fig. 4, which compares the vertical distributions of copepodids at equivalent times of year. Although the interpretation for the WSC is uncertain, the springtime ascent in the SS precedes that in the EWS by about 2 mo. C. acutus also resides in the surface waters for longer in the northern region, from November to February, compared to from about late January to early March in the EWS.

\section{Developmental stage structure}

Age structure can vary widely among stations sampled at similar times of year (Fig. 5) This probably reflects both environmental variability and imprecision in stage structure estimation, particularly where numbers are low at the northern limit of the study area. Fig. 5 therefore includes trend lines, which link stage frequencies calculated from simple means from stations grouped at similar times of year (Tables 1 to 3 ). 
Fig 4. Calanoides acutus. Vertical distribution of copepodids in the 3 regions. Pooled groups of stations (or transects) that came from similar times of year (1.e. no more than 2 wk apart) were selected (Tables 1 to 3 ) to allow regional comparisons of timing. The scale (see key) is as a percentage of maximum abundance (no. $1000 \mathrm{~m}^{-3}$ ) found within the sampled water column
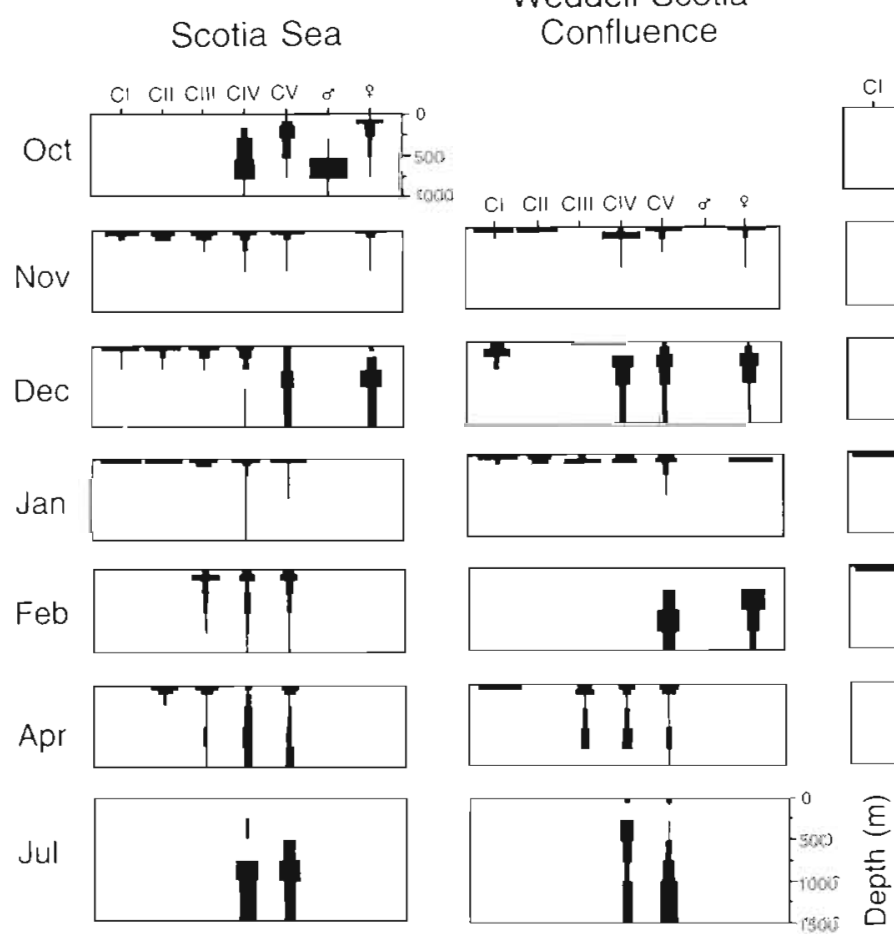

Eastern

Weddell Sea
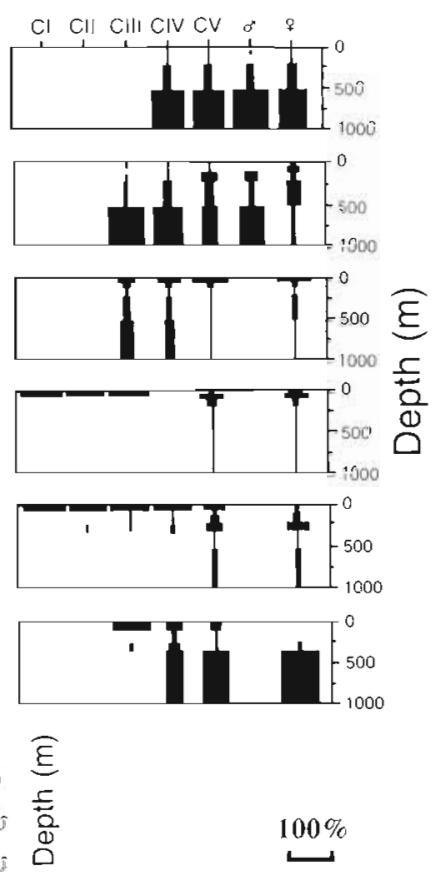

Adult males are abundant for about $2 \mathrm{mo}$ in late winter; August-September in the 2 northern zones and October-November in the EWS (but note the absence of mid winter samples in the EWS). Males have reduced mouthparts and probably die after spawning. The disappearance of males coincides with the appearance of adult females, so the short period of their cooccurrence is the mating period. This is at depth (Fig. 4), and before the ascent of females to the surface layers (Marin 1988, Schnack-Schiel \& Hagen 1995). The rise of females before the spring bloom precedes that of the late stage copepodites (CIV and CV) also present at this time. The new summer generation of early copepodids appears in early spring, at about the reported time of the first increases in phytoplankton in the respective regions: about November-December in the SS and WSC (El-Sayed \& Weber 1982, Priddle et al. 1986, Jacques \& Panouse 1991), and about January in the EWS (Nöthig et al. 1991). It follows, therefore, that to allow time for egg hatching and naupliar development at these temperatures, egg laying must start before chlorophyll a concentrations increase. This was suggested for the Weddell Sea from the timing of appearance of nauplii (Fransz 1988) and from gonad maturity and lipid levels (Schnack-Schiel \& Hagen 1994, 1995, Hagen \& Schnack-Schiel 1996).

The copepodid stages are concentrated mainly in the chlorophyll a-rich top $50 \mathrm{~m}$ layer during the summer months (Fig. 4), and about 1.5 mo after the first appearance of summer generation CIs, there is a sharp in- crease in ClVs (Fig 5) In common with the latitudinal differences in timing already described, this occurs at a similar time in the 2 northern zones but about 2 mo later in the EWS. Fig. 4 shows that in autumn the older copepodids are located deeper than younger stages, and throughout autumn each stage sinks. Several of the individual stations (as well as the group averages in Fig. 4) show a bimodal depth distribution of CIV, CV and adult females in autumn, with maxima usually in the top $100 \mathrm{~m}$ and below $250 \mathrm{~m}$. This has been found to occur during autumn in other studies (e.g. Huntley \& Escritor 1991).

The overwintering stages are predominantly CIV and $\mathrm{CV}$, both of which have extensive stores of wax esters, unlike the early copepodites (Schnack-Schiel \& Hagen 1995). The ratios of CIV to CV during winter vary greatly between adjacent stations, and no regional or interannual pattern was detected. In common with other findings (e.g Andrews 1966) these copepodites were overwintering at depths mainly between 500 and $1500 \mathrm{~m}$.

\section{DISCUSSION}

\section{Regional abundance}

It is well known that Calanoides acutus inhabits the southern part of the Antarctic Circumpolar Current and the East Wind Drift (e.g. Andrews 1966), but Fig. 2 shows 


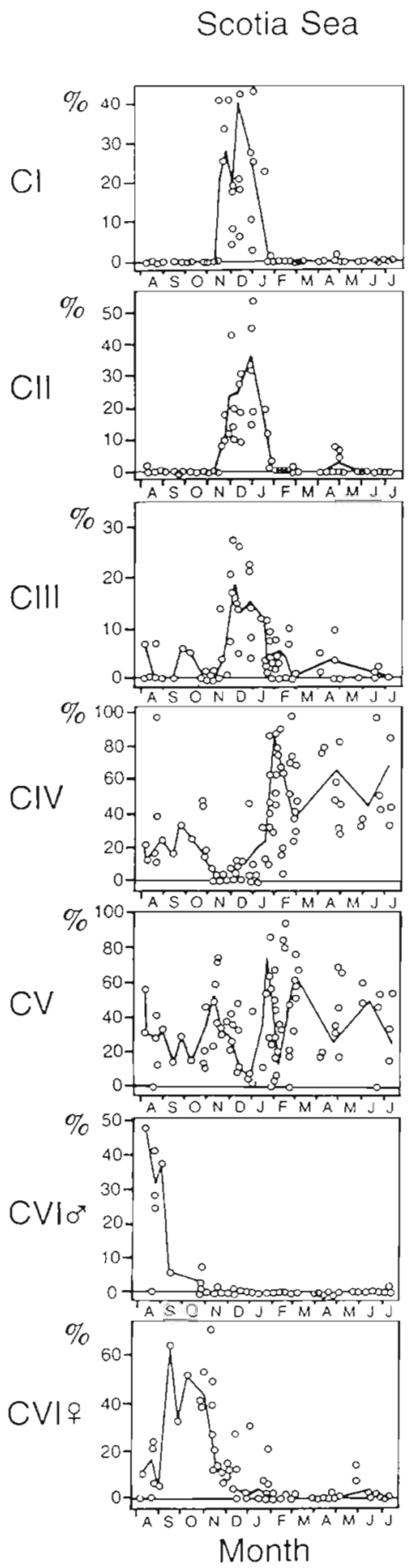

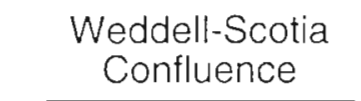
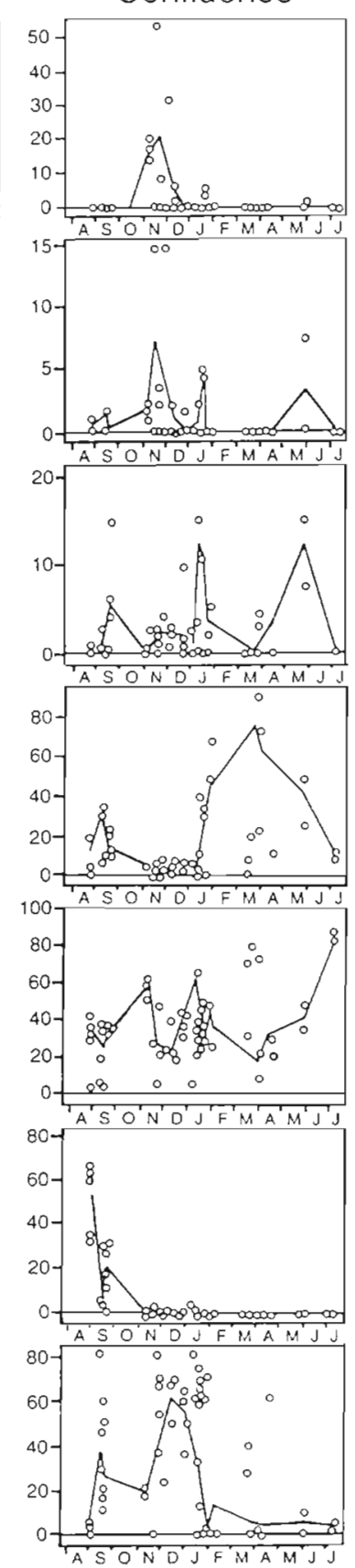

Month that abundance was particularly low in the WSC area. This is unlikely to have resulted from differences in sampling gear, because several regional comparisons with standardised sampling have shown a lower abundance in the WSC than in the SS (e.g. Marin 1987. Atkinson 1991). Likewise, transects across the Weddell Sea (Bathmann et al. 1993) show lower abundance of $C$. acutus in the WSC/northern Weddell Sea than in the EWS.

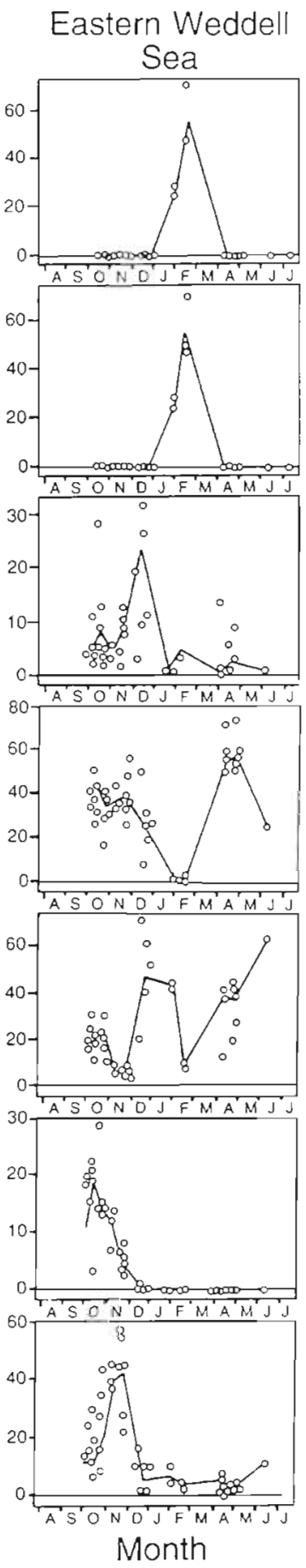

Fig. 5. Calanoides acutus. Percentage composition of developmental stages within the 3 regions. Each data point represents a station and the trend lines link mean values for groups of stations defined in Tables 1 to 3 . For clarity several data points have been omitted. Note that the $y$-axis scale varies
The reason for this is obscure, because the WSC is in the heart of the temperature range of this species and is a seemingly favourable environment (Table 5), with marginal ice zone structure and comparatively high chlorophyll a concentrations (Table 5). The Gerlache Strait area and the Antarctic Peninsula upstream of the WSC seem to be favourable environments for Calanoides acutus (Huntley \& Escritor 1991). There are no 
obvious differences in the life cycle between the WSC and the SS; the timing, development rates and stage structures are similar. However, abundance and vertical distribution are highly variable in the WSC. Note that this region encompasses the northern Weddell Sea as well as the confluence itself, which can be quite restricted in extent at the longitudes of most of the stations (Foster \& Middleton 1984). Several authors have also reported the absence of a bloom in the Northern Weddell Sea, immediately south of the WSC. This was attributed to high grazing pressure, possibly by Euphausia superba, which is very numerous in this region (Jacques \& Panouse 1991), and to unsuitable physical conditions for a marginal ice bloom (Jochem et al. 1995). We can only speculate that environmental variability in this transition zone, or competition/predation from other species such as E. superba, exerted some control over population size.

\section{Timing of the life cycle}

Calanoides acutus is considered to be mainly herbivorous (Voronina \& Sukhanova 1976. Hopkins \& Torres 1989. Atkinson et al. 1996) and it is also agreed that individuals at depth do not feed (Andrews 1966, Schnack-Schiel et al. 1991, Bathmann et al. 1993). Therefore their presence in the upper mixed layer (Figs. $3 \& 4$ ) could reflect the timing and duration of the primary production season in the various regions. This, and the appearance of the corresponding copepodite stages (Fig 5), is about 2 mo later in the EWS than in the SS and WSC, and the population develops in the surface layer for a shorter time in the southern region. The lag in timing at higher latitudes was first described by Voronina $(1970,1978)$ for C. acutus, Calanus propinquus and Rhincalanus gigas in the Indian Ocean sector. She proposed that this corresponded to a latitudinal lag in the timing of the phytoplankton maximum (Hart 1942), a reasonable suggestion for a species relying on phytoplankton. We are not aware of any seasonal data on ingestable phytoplankton $(>5 \mu \mathrm{m})$ in our study area which are strictly comparable with Fig 3. The ice-free months are generally January to March in the EWS (Gloersen et al. 1992), so this is the likely window for water column primary production in this area. Offshore blooms in the SS, however, have been observed well before this in November-December (ElSayed \& Weber 1982, Priddle et al. 1986, Jacques \& Panouse 1991).

Despite the lag in life cycle timing between the EWS and the SS, Figs. 4 \& 5 suggest that it does not follow a simple or regular temperature- or latituderelated pattern. The life cycle timing in the WSC seems to be very similar to that in the SS to its north; it is only in the EWS that the timing is delayed, relative to the other 2 regions

\section{Development rates}

Previous studies have reached opposing conclusions about moulting rates of Calanoides acutus. The studies of Andrews (1966) and Atkinson (1991), mainly in the Antarctic Circumpolar Current, suggest that development from $\mathrm{Cl}$ to ClI takes about 1 mo. Huntley \& Escritor (1991) and Chojnacki \& Weglěnska (1984), however, have suggested much slower moulting rates, about 1 mo per stage in the Bransfield Strait area (Antarctic Peninsula). Our results support the former works, that moulting from CI to CIV takes about $1.5 \mathrm{mo}$ (Table 6). The apparently slow moulting in the Bransfield Strait area either might be a feature of that region or may reflect the sampling, which was mainly in the surface layers during the summer-autumn, when the older copepodids were migrating to depth.

Given that the SS, WSC and EWS environments are so different, the similarity in moulting rates (Table 6) is surprising Temperature and food availability are thought to be the main factors controlling growth, and although their relative importance is controversial (e.g. Clarke \& Peck 1991, cf. Huntley \& Lopez 1992), it appears to vary between species and populations (e.g. Klein Breteler et al. 1995) The mean surface temperature across the SS stations was $2.4^{\circ} \mathrm{C}$ in November, December and January, and that in the equivalent growing season in the EWS (January and February) was $-1.2^{\circ} \mathrm{C}$. Although this 3 to $4^{\circ} \mathrm{C}$ difference might cause a slightly lower development rate in the colder region (all other factors being equal), perhaps balanced against this is better food availability in the WSC and EWS. We have no comparable data on copepodid dry masses from which to calculate growth rates in the various regions. Copepodite stages tend to be larger in colder water, and if this is the case for Calanoides acutus, then mass-specific growth rates were rather faster in the EWS than in the SS

Table 6. Time delay between the appearance of adult females in winter-spring and the summer generation of CIV (first row) and between the summer generations $\mathrm{CI}$ and CIV (second row). The values are in days using a criterion of the time when a stage reaches $20 \%$ of the population' to define when it appears (these are based on the trend lines in Fig. 5). Values in parentheses were calculated (where possible) using a $40 \%$ criterion

\begin{tabular}{|lccc|}
\hline Development & Scotia Sea & $\begin{array}{c}\text { Weddell-Scotia } \\
\text { Confluence }\end{array}$ & $\begin{array}{c}\text { Eastern } \\
\text { Weddell Sea }\end{array}$ \\
\hline CVIo to CIV & $122(126)$ & $128(130)$ & $133(132)$ \\
CI to CIV & $49(41)$ & 53 & $41(49)$ \\
\hline
\end{tabular}




\section{a) One year life cycle}

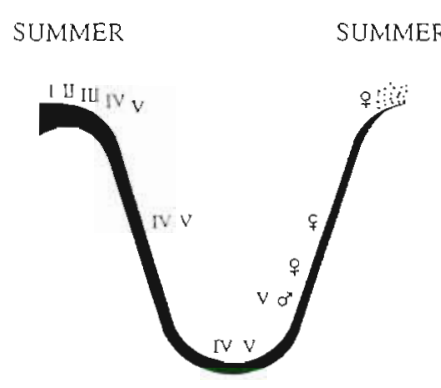

\section{b) Two year life cycle}

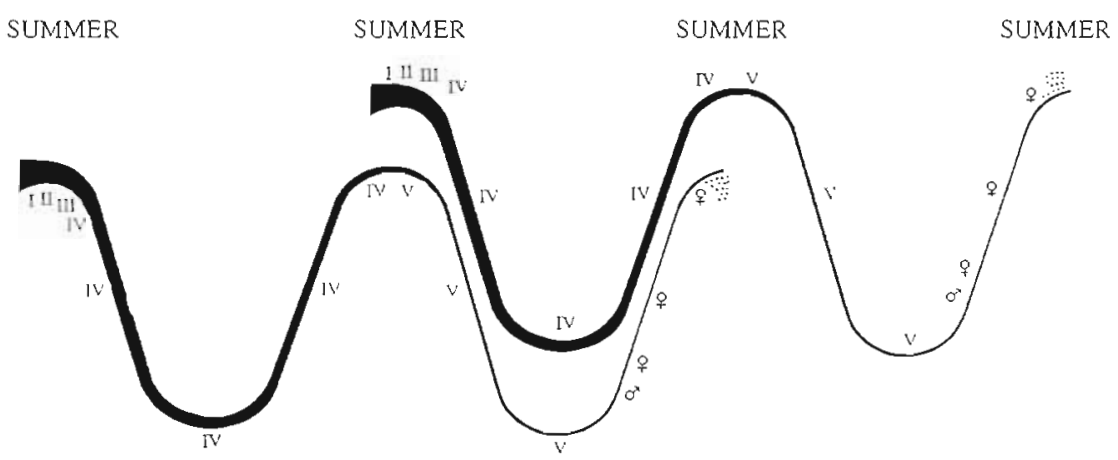

Fig. 6. Calanoides acutus. Schematic representations of alternative life cycles (a) for a 1 yr and (b) for a 2 yr life cycle, showing overlapping of generations. Stippling denotes main egg laying period. Progressive thinning of cohort lines indicates mortality

\section{Life cycle duration}

Until recently the life span of Calanoides acutus has been assumed to be 1 yr (Voronina 1978, Marin 1988). This model (Fig. 6a) comprises growth and moulting in the surface layers during summer with CIV and CV copepodids overwintering at depth. These moult to adult males and females in late winter, which mate and complete the life cycle with egg laying near the surface in spring. That not all of the overwintering copepodids moult to adults was noted by Atkinson (1991), but their fate during their second summer is uncertain because they become hard to distinguish from CVs of the new summer generation. The recent suggestions of a $2 \mathrm{yr}$ life cycle (Drits et al. 1994, Pasternak et al. 1994) were based primarily on lipid and physiological data from autumn. They found 2 groups of $C$. acutus: a lipid-poor group, active in the surface layers, concurrent with a lipid-rich group at depth, with lower metabolic rates. These authors suggested that the lipid-poor copepodids had developed from eggs that summer, while the lipid-rich group were over 1 yr old, having spent that summer increasing their lipids to sustain moulting to adulthood and spawning the following winter. This
2 yr model, taken from Drits et al. (1994), is shown in Fig. 6b.

Our data on seasonal age structure and mortality provide complementary information on life cycle duration. If the life cycle is $2 y r$, then the fact that mortality progressively reduces each year class would mean that at any given time, individuals in their first year would normally outnumber those in their second year. Mortality is suggested diagrammatically by the progressive thinning of the cohort lines in Fig. 6. The percentage of adults in the population during the late winter mating/ spawning period is therefore an indicator of whether a 1 or 2 y model is most suitable. If it is a 1 yr cycle, then most of the population would moult to adults in late winter, but if it is $2 \mathrm{yr}$, most would remain as CIV and CV. The population mortality rate would dictate the expected ratio: the higher the mortality, the higher the ratio of late stage copepodites to adults during late winter (see Fig. $6 \mathrm{~b}$ for the relative thickness of the cohort lines in late winter). We estimated mortality of the whole population for the autumn-winter period from when CIVs peak in late summer until adult males peak in late winter (Fig 5). This restricted period was needed to avoid both the summer period of recruitment and the spring, when adults were dying. The average estimated mortality of the EWS population in autumnwinter is $0.0059 \mathrm{~d}^{-1}$, and that for the SS is similar at $0.0070 \mathrm{~d}^{-1}$ (Fig. 7). Abundance in the WSC was too variable for the regression to be significant. If the mortality rate of the EWS population was calculated over $1 \mathrm{yr}$, only $1.1 \%$ of the cohort would remain. This would imply that for a 2 yr life cycle, the late stage copepodites would need to outnumber adults by about $9: 1$ The proportions of adults in the populations during the late winter spawning period are clearly higher than this; in the SS and WSC they exceed $75 \%$ of the population (Fig. 5). This suggests a mainly 1 yr life cycle in these regions. The percentage is rather lower in the EWS, where adults reached only about half of the population in late winter

Although this simple analysis suggests a predominantly 1 yr life cycle in all 3 regions, several other factors complicate the analysis. First. Hagen \& Schnack-Schiel (1996) observed bimodal frequency distributions of lipid content among prespawning adult 

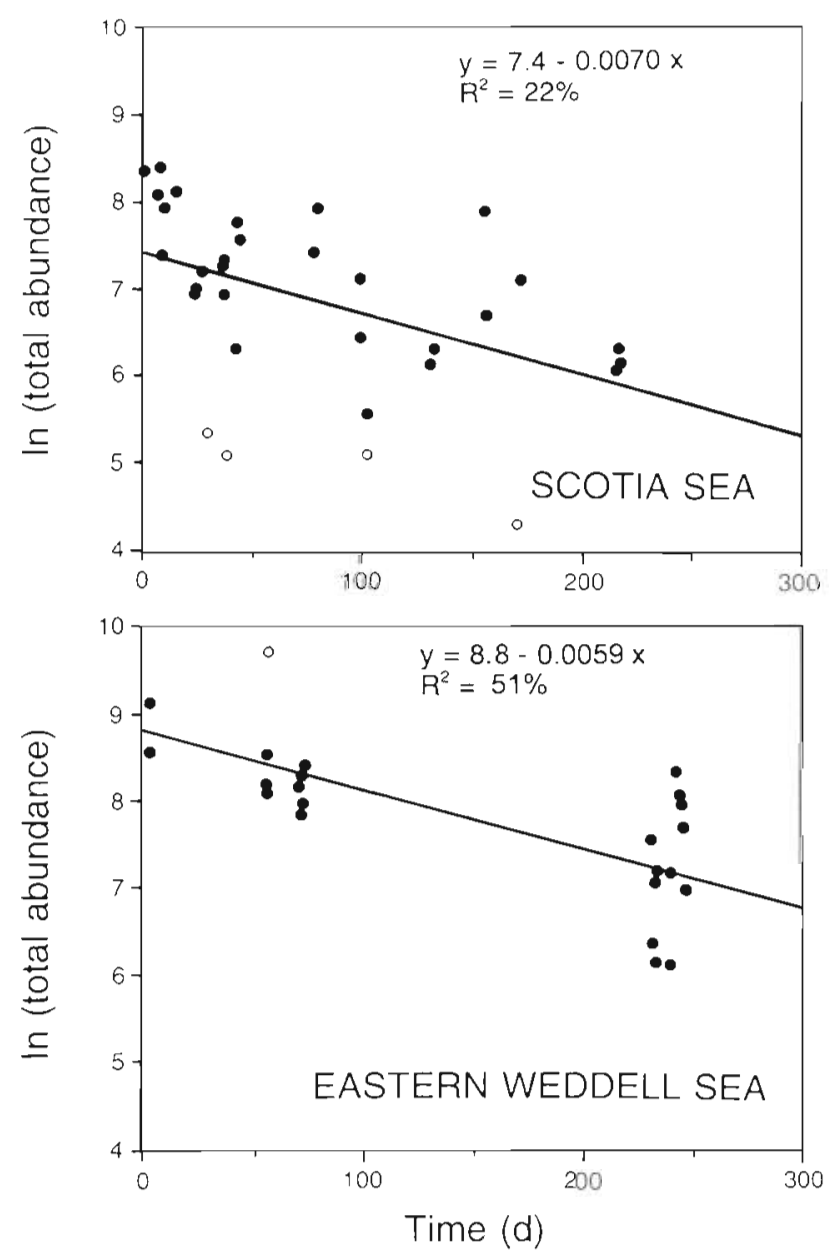

Fig 7. Calanoides acutus. Total abundance under $1 \mathrm{~m}^{2}$ against time, plotted from the end of recruitment of summer generation CIV into the population (i.e. when CIV peak in autumn) to the time of maximum male abundance in late winter (see Fig. 5) in the Scotia Sea and Eastern Weddell Sea. Each point is a sampling station, and outliers (open symbols; identified by a prior regression analysis) are removed from the regression equations presented. Both regressions are significant $(p<0.001)$

females, and suggested that some of the females did not die after spawning but survived a further year This longevity of adult females would tend to increase their percentage of the population in late winter. In both the EWS and the WSC, females comprise a low percentage of the population year-round (Fig. 5), possibly supporting Hagen \& Schnack-Schiel's (1996) suggestion. However, female abundance in the EWS during summer, autumn and early winter averaged only $15 \%$ of that during the main spawning period, so probably only a minority survive to spawn again the following year

A second factor is that we could have overestimated winter mortality. At several of the winter stations, sam- pling was only to $1000 \mathrm{~m}$ (Tables 1 to 3 ), so at these 25 to $50 \%$ of the population could have been below our sampling depth (Andrews 1966). If mortality was recalculated assuming a worst case, that $50 \%$ of the population were below the winter sampling depth, the late stage copepodites would still need to outnumber adults during the spawning period by about 4:1 for a 2 yr life cycle. We believe that our estimated mortality rates are reasonable, being in the range of those measured for the Calanoides acutus population in Bransfield Strait in late winter (Huntley et al. 1994) and for other large boreal copepods (Matthews et al. 1978, Aksnes \& Magnesen 1983). Our estimates also do not cover the summer period when the copepodids are feeding in the surface layers and thus presumably exposed to greater predation (Ohman \& Wood 1995, Aksnes 1996).

Northern Hemisphere studies have shown regional variations in life cycle durations of the Arctic and boreal species Calanus glacialis, Calanus hyperboreus and Calanus finmarchicus, which may depend on temperature and food (see Smith \& Schnack-Schiel 1990). Conover et al. (1991) suggested that one adaptation of C. hyperboreus to a variable environment was the ability, even of early copepodids, to overwinter. Likewise, the variable stage structures of Calanoides acutus in winter (Fig. 5) might reflect environmental variability prior to sampling. Summer moulting rates are similar in all 3 regions, so perhaps it is the shortness of the growing season in the EWS which is responsible for a lower proportion of adults in the population in late winter. Individuals encountering poor feeding conditions, or with insufficient time to grow to lipid-rich CVs in their first summer, can probably survive to complete their life cycle in 2 yr. However the mortality risk of surviving a whole extra year probably means that only a small percentage of each cohort actually achieves this. The intense variability within the Southern Ocean at all scales is being increasingly recognised (see Huntley \& Niiler 1995). Perhaps the potential for slow-growing or latedeveloping copepodids to extend their life cycle is a 'bet-hedging' mechanism, preventing the individuals from dying (and the cohort from crashing) if the environment in any single season is particularly harsh.

What dictates the comparatively long ( 1 yr) life cycle of Calanoides acutus? Clarke \& Peck (1991) suggested that highly seasonal primary production meant that, on an annual average, little food was available to polar herbivores. The short summer period when $C$. acutus can feed in the surface layers (Fig. 3) might support this. However Huntley \& Lopez (1992) argued that temperature, rather than food availability, tended to dictate copepod growth rate. A recent compilation of data (Atkinson in press) suggests that even during intense spring blooms, $C$. acutus has low rates of food intake and carbon expenditure for respiration and egg 
production. These mass-specific rates are similar to those of Arctic calanoids (see Smith \& Schnack-Schiel 1990, Conover \& Huntley 1991), but much lower than those of smaller, lower latitude calanoids. This suggests that a factor other than food, such as temperature, may slow growth during the short periods of food saturation. So possibly both food availability and temperature are responsible, at different times of the year, for the slow growth and long generation time of C. acutus compared to those of warmer water calanoids.

Acknowledgements. We thank Drs U. Bathmann and V. Marin for making their data avallable to us. We are grateful to Drs J. Priddle, A. Hirst and Prof. A. Clarke for constructive comments on earlier drafts of this manuscript.

\section{LITERATURE CITED}

Aksnes DL (1996) Natural mortality, fecundity and development time in marine planktonic copepods - implications of behaviour. Mar Erol Prog Ser 131:315-316

Aksnes DL, Magnesen T (1983) Distribution, development, and production of Calanus finmarchicus in Lindaspollene, western Norway, 1979. Sarsia 68:195-208

Andrews KJH (1966) The distnbution and life history of Calanoides acutus (Giesbrecht). Discovery Rep 34:1-116

Atkinson A (1989) Distribution of six major copepod species around South Georgia during an austral winter. Polar Biol $10: 81-88$

Atkinson A (1991) Life cycles of Calanoides acutus, Calanus simillimus and Rhincalanus gigas (Copepoda: Calanoida) within the Scotia Sea. Mar Biol 109:79-91

Atkinson A (in press) Life cycle strategies of epipelagic copepods in the Southern Ocean. J Mar Syst Spec Issue

Atkinson A, Peck JM (1990) The distribution of zooplankton in relatıon to the South Georgia shelf in summer and winter. In: Kerry KR, Hempel G (eds) Antarctic ecosystems. Ecological Change and Conservation. Springer-Verlag, Berlin, p 159-165

Atkinson A, Shreeve RS. Pakhomov EA, Prlddle J, Blight SP, Ward P (1996) Zooplankton response to a phytoplankton bloom near South Georgia, Antarctica. Mar Ecol Prog Ser 144:195-210

Atkinson A, Ward P. Williams R, Poulet SA (1992) Feeding rates and dicl vertical migration of copepods near South Georgia: comparison of shelf and oceanic sites. Mar Biol $114: 49-56$

Baker AdeC (1954) The circumpolar continuity of Antarctic plankton species. Discovery Rep 27:201-218

Bathmann UV, Makarov RR, Spiridinav VA. Rohardt G [1993 Winter distribution and overwintering strategies of the Antarctic copepod species Calanoides aculus, Rhincalanus gigas and Calanus propinquus (Crustacea, Calanoida) in the Weddell Sea. Polar Biol 13:333-346

Chojnacki J, Weglěnska T (1994) Perrodicity of composition, abundance, and vertical distribution of summer zooplankton $(1977 / 1978$ ) in Ezcurra Inlet, Admiralty Bay (King George Island, South Shetland). J Plankton Res 6: $997-1017$

Clarke A, Peck LS (1991) The physiology of polar marine zooplankton. In: Sakshaug E, Hopkins CCE, Oritsland NA reds) Proceedings of the Pro Mare Symposium on Polar Marine Ecology, 12-16 May 1990. Polar Res 10: $355-369$
Conover RJ, Harris LR, Bedo AW (1991) Copepods in cold oligotrophic waters - how do they cope? Bull Plankton Soc Jpn, Spec Vol, p 177-199

Conover RJ, Huntley M (1991) Copepods in ice-covered seas - distribution, adaptations to seasonally limited food, metabolism, growth patterns and life cycle strategies in polar seas. J Mar Sys 2:1-41

Drits AV, Pasternak AF, Kosobokova KN (1994) Physiological characteristics of the Antarctic copepod Calanoides acutus during late summer in the Weddell Sea. Hydrobiologia 292/293:201-207

El-Sayed SZ, Weber LH (1982) The spatial and temporal variations in phtyoplankton biomass and primary productivity in the southwest Atlantic and the Scotıa Sea. Polar Bıol 1 $83-90$

Foster TD, Middleton JH (1984) The oceanographic structure of the Eastern Scotia Sea - I. Physical oceanography Deep Sea Res 31:529-550

Foxton P (1956) The distribution of the standing stock of zooplankton in the Southern Ocean. Discovery Rep 28 $191-236$

Fransz HG (1988) Vernal abundance, structure and development of epipelagic copepod populations of the eastern Weddell Sea (Antarctica). Polar Biol 9:107-114

Gloersen P, Campbell WJ, Cavalieri DJ, Comiso JC, Parkinson CL, Zwally HJ (1992) Arctic and Antarctic sea ice, 1978-1987: Satellite passive-microwave observations and analysis. National Aeronautics and Space Administration, Washington, DC

Gordon AL (1988) Spatial and temporal variability within the Southern Ocean. In: Sahrhage D (ed) Antarctic Ocean and resources variability. Springer-Verlag, Berlin, p 41-56

Graeve M, Hagen W, Kattner G (1994) Herbivorous or omnivorous? On the significance of lipid compositions as trophic markers in Antarctic copepods. Deep Sea Res 41:915-924

Hagen W, Schnack-Schiel SB (1996) Seasonal lipid dynamics in dominant Antarctic copepods: energy for overwintering or reproduction? Deep Sea Res 43: 139-158

Hart TJ (1942) Phytoplankton periodicity in Antarctic waters Discovery Rep 11:261-356

Hopkins TL (1971) Zooplankton standing crop in the Pacific sector of the Antarctic. Antarct Res Ser 17:347-362

Hopkins TL, Ainley DG, Torres JJ, Lancraft TM (1993) Trophic structure in open waters of the marginal ice zone in the Scotia-Weddell confluence region during spring (1983). Polar Biol 13:389-397

Hopkins TL, Torres JJ (1989) Midwater food web in the vicinity of a marginal ice zone in the western Weddell Sea. Deep Sea Res 36:543-560

Huntley ME, Escritor F (1991) Dynamics of Calanoldes acutus (Copepoda: Calanoida) in Antarctic coastal waters. Deep Sea Res 38:1145-1167

Huntley ME, Lopez MDG (1992) Temperature-dependent production of marme copepods: a global synthesis. Am Nat 140:201-242

Huntley ME, Niiler PP (1995) Physical control of populatron. dynamics in the Southern Ocean. ICES J Mar Sci 52: $457-468$

Huntley ME, Zhou M, Lopez MDG (1994) Calanoides acutus in Gerlache Strait, Antarctica II. Solving an inverse problem in population dynamics. Deep Sea Res 41:209-227

Jacques G (1989) Primary production in the open Antarctic Ocean dunng the austral summer. A review. Milieu 39: $1-17$

Jacques G, Panouse M (1991) Biomass and composition of size fractionated phytoplankton in the Weddell-Scotia Confluence area. Polar Biol 11:315-328 
Jochem FJ, Mathot S, Quéguiner B (1995) Size fractionated primary production in the open Southern Ocean in austral spring. Polar Biol 15:381-392

Kattner G, Graeve M, Hagen W (1994) Ontogenetic and seasonal changes in lipid and fatty acid/alcohol compositions of the dominant Antarctic copepods Calanus propinquus, Calanoides acutus and Rhincalanus gigas. Mar Biol 118: $637-644$

Klein Breteler WCM, Gonzalez SR, Schogt N (1995) Development of Pseudocalanus elongatus (Copepoda, Calanoida) cultured at different temperature and food conditions. Mar Ecol Prog Ser 119:99-110

Lancelot C, Mathot S, Veth C, De Baar H (1993) Factors controlling phytoplankton ice-edge blooms in the marginal ice-zone of the northwestern Weddell Sea during sea ice retreat 1988: field observations and mathematical modelling. Polar Biol 13:377-387

Laubscher RK, Perissinotto R, McQuaid CD (1993) Phytoplankton production and biomass at frontal zones in the Atlantic sector of the Southern Ocean. Polar Biol 13: $471-481$

Lopez MDG, Huntley ME, Lovette JT (1993) Calanoides acutus in Gerlache Strait, Antarctica. I. Distribution of late copepodite stages and reproduction during spring. Mar Ecol Prog Ser 100:153-165

Lutejeharms JRE, Walters NM, Allanson BR (1985) Oceanic frontal systems and biological enhancement. In: Siegfried WR, Condy PR, Laws RM (eds) Antarctic nutrient cycles and food webs. Springer-Verlag, Berlin, p 11-21

Mackintosh (1946) The Antarctic Convergence and the distribution of surface temperatures in Antarctic waters. DisCovery Rep 23:177-212

Marin V (1986) Distribution and life cycle of three Antarctic copepods (Calanoides acutus, Calanus propinquus and Rhincalanus gigas). PhD thesis, University of Califormı, San Diego

Marin V (1987) The oceanographic structure of the eastern Scotia Sea: Part VI - distribution of copepod species in relation to hydrography in 1981. Deep Sea Res 34:105-121

Marin V (1988) Qualitative models of the life cycles of Calanoides acutus, Calanus propinquus and Rhincalanus glgas. Polar Biol 8:439-446

Martin JH, Gordon RM, Fitzwater SE (1990) Iron in Antarctic waters. Nature 345:156-158

Matthews JBL, Hestad L, Bakke JLW (1978) Ecological studies in Korsfjorden. Western Norway. The generations and stocks of Calanus hyperboreus and C. finmarchicus 1971-1974. Oceanol Acta 1:274-284

Nöthig FM, von Bodungen B, Sui Q (1991) Phyto- and protozooplankton biomass during austral summer in surface waters of the Weddell Sea and vicinity. Polar Biol 11: 293-304

Nowlin WD, Klinck JM (1986) The physics of the Antarctic Circumpolar Current. Rev Geophys 24:469-491

Ohman MD, Wood SN (1995) The inevitability of mortality ICES J Mar Sci 52:517-522

Ommanney FD (1936) Rhincalanus gigas (Brady), a copepod of the southern macroplankton. Discovery Rep 5:277-384

Ottestad P (1932) On the biology of some southern Copepoda. Halvrädets Skr 5:1-61

Pasternak AF, Kosobokova KN, Drits AV (1994) Feeding, metabolism and body composition of the dominant Antarctic copepods with comments on their life cycles. Russian J Aquat Ecol 3:49-62

Priddle J, Heywood RB, Theriot E (1986) Some environmental

This article was submitted to the editor factors influencing phytoplankton in the Southern Ocean. Polar Biol 5:65-79

Savidge G, Priddle J, Gilpin LC, Batmann U, Murphy EJ, Owens NJP, Pollard RT, Turner DR, Veth C. Boyd PW (1996) An assessment of the role of the marginal ice zone in the carbon cycle of the Southern Ocean. Antarct Sci 8 : $349-358$

Schnack-Schiel SB, Hagen W (1994) Life cycle strategies and seasonal variations in distribution and population structure of four dominant calanoid copepod species in the eastern Weddell Sea, Antarctica. J Plankton Res 16 : $1543-1566$

Schnack-Schiel SB, Hagen W (1995) Life-cycle strategies of Calanoides acutus, Calanus propinquus, and Metridia gerlachei (Copepoda: Calanoida) in the eastern Weddell Sea, Antarctica. ICES J Mar Sci 52:541-548

Schnack-Schiel SB, Hagen W, Mizdalski E (1991) Seasonal comparison of Calanoides acutus and Calanus propinquuus (Copepoda: Calanoida) in the southeastern Weddell Sea, Antarctica. Mar Ecol Prog Ser 70:17-27

Smith SL, Schnack-Schiel SB (1990) Polar zooplankton. In: Smith WO (ed) Polar oceanography, Part B: chemistry, biology, and geology. Academic Press, San Diego, p 527-587

Smith WO Jr, Nelson DM (1985) Phytoplankton bloom produced by a receding ice-edge in the Ross Sea: spatial coincidence with the density field. Science 227:163-165

Sullivan CW, MCClain CR, Comiso JC, Smith WO (1988) Phytoplankton standing crops within Antarctic ice edge assessed by satellite remote sensing. J Geophys Res 93:487-498

Tréguer P, Jacques G (1992) Dynamics of nutrients and phytoplankton, and fluxes of carbon, nitrogen and silicon in the Antarctic Ocean. Polar Biol 12:149-162

Vervoort W (1965) Notes on the biogeography and ecology of free-living marine Copepoda. In: van Oye P, van Mieghem $\mathrm{J}$ (eds) Biogeography and ecology in Antarctica. Junk. The Hague, p 381-401

Vladimirskaya YeV (1978) Age composition of winter populations of abundant copepod species in the southern part of the Scotia Sea. Oceanology 18:202-204

Voronina NM (1970) Seasonal cycles of some common Antarctic copepod species. In: Holdgate MW (ed) Antarctic ecology. Academic Press, London, p 162-172

Voronina NM (1978) Variability in ecosystems. In: Charnock $\mathrm{H}$, Deacon GER (eds) Advances in oceanography. Plenum Press, New York, p 221-243

Voronina NM, Sukhanova IN (1976) Composition of food of massive species of Antarctic copepods. Oceanology 16 : $614-616$

Voronina NM, Vladimirskaya YeV, Zmiyevskaya MI (1978) Seasonal variations in the age composition and vertical distribution of common zooplankton species in the Southern Ocean. Oceanology 18:335-338

Ward P, Atkinson A, Murray AWA, Williams R, Poulet SA (1995) The summer zooplankton community at South Georgia: biomass, vertical migration and grazing. Polar Biol 15:195-208

Whitehouse MJ, Priddle J, Trathan PN, Brandon MA (1996) Substantial open-ocean phytoplankton blooms to the north of South Georgia, South Atlantic, during summer 1994. Mar Ecol Prog Ser 140:187-197

Whitworth T III, Nowlin WD Jr, Orsi AH, Locarnini RA, Smith SG (1994) Weddell Sea shelf water in the Bransfield Strait and Weddell-Scotia Confluence. Deep Sea Res 41: $629-641$

Manuscript first received: December 30, 1996 Revised version accepted: February 20, 1997 